Порівняння результатів самооцінки вихователів та їхніх відповідей на запитання про мову спілкування в різних комунікативних сферах свідчить про завищену самооцінку інформантів. Проаналізуємо: тільки 10,8 \% опитаних педагогів мають україномовну практику спілкування поза дошкільним закладом, але при цьому вказують на високий рівень володіння мовою $30 \%$ вихователів; 63\% фахівців україномовних закладів і $78 \%$ російськомовних оцінюють свій рівень навичок україномовлення як середній, хоча вказують на повну відсутність практики спілкування українською мовою поза ДНЗ. Зауважимо, спеціальні спостереження та наукові джерела засвідчують необхідність більш або менш постійної мовленнєвої практики як умови володіння мовою.

Отже, результати дослідження виявили в цілому несприятливі умови для опанування дітьми дошкільного віку української мови в стихійному соціомовленнєвому середовищі південно-східного регіону країни. У родинній та побутовій комунікації діти не мають можливості шляхом наслідування засвоювати українську мову, оскільки контактують переважно 3 російськомовним оточенням. Незадовільною для засвоєння дітьми української мови виявилася організація мовного режиму в дошкільних навчальних закладах південно-східного регіону як з україномовним, так і російськомовним статусом.

\title{
Література
}

1. Белл Р.Социолингвистика: цели, методы и прийомы : [моногрофия] / Р. Г. Белл. - М.: Международные отношения, 1980. - 318 с. 2. Кісь Р. Етнічна маргінальність і мовлення (про деякі аспекти етнолінгвістичної ситуації в містах України / Р. Кісь // Урок української. - 1999. - № 2-3. - С. 6-12. 3. Кочерган М. П. Загальне мовознавство: [підручник] / М. П. Кочерган. - К. : Видав. центр «Академія», 1998. - 288 с. 4. Масенко Л. Нариси з соціолінгвістики: [монографія] / Л. Масенко. - К. : Видав. дім «Києво-Могилянська академія», 2010. - 243 с. 5. Українська мова. Енциклопедія ; ред. кол.: В. М. Русанівський та ін. - 2-е вид., випр. і доп. - К. : Укр. енциклопедія, 2000. - 752 с. 6. Швейцер А. Д. Введение в социолингвистику : [учеб. пособ]. / А. Д. Швейцер, Л. Б. Никольский. - М. : Высшая школа, 1978. - 216 с. 7. Ferguson С. К. A. Diglossia. - Word, 1962. - vol. 15. - № 2. - P. 3-11.

УДК [371:811.161.2](477.75)

Ю К. Картава, ст. викладач, Євпаторійський інститут сочіальних наук РВНЗ «Кримський гуманітарний університет» (м. Ялта)

\section{СТАН ВИКЛАДАННЯ УКРАЇНСЬКОЇ МОВИ В ЗАКЛАДАХ ОСВІТИ АВТОНОМНОЇ РЕСПУБЛІКИ КРИМ}

\footnotetext{
Картава Ю. К. Стан викладання української мови в закладах освіти Автономної Республіки Крим

У статті висвітлено сучасний стан викладання української мови в загальноосвітніх закладах АР Крим, проаналізовано нормативну базу і з'ясовано основні тенденції щодо підвищення рівня викладання української мови вчителями-філологами.

Ключові слова: викладання української мови, загальноосвітні заклади, підвищення рівня викладання, учитель-філолог.
}

Картавая Ю. К. Состояние преподавания украинского языка в учреждениях образования Автономной Республики Крым.

В статье рассматривается современное состояние преподавания украинского языка в общеобразовательных учреждениях АР Крым, анализируется нормативная база и выделяются основные тенденции повышения уровня преподавания украинского языка учителями-филологами.

Ключевые слова: преподавание украинского языка, общеобразовательные учреждения, повышение уровня преподавания, учитель-филолог.

Kartavaya Y. K. Condition of teaching the Ukrainian language in secondary schools of the Crimean Autonomous Republic. 
The article outlines the modern state of teaching the Ukrainian language in secondary schools of the Crimean Autonomous Republic, analyzes the normative base and finds out major tendencies of raising the level of teaching the Ukrainian language by the teachers-philologists.

Key words: teaching the Ukrainian language, secondary schools, raising the level of teaching, teachers-philologists.

Українська освіта обирає напрям на інтеграцію до європейського співтовариства, тому XXI століття - «це століття професіоналів, в якому буде здійснено перехід від кваліфікації до компетенції. Саме компетенції дають змогу знаходити рішення в будь-яких професійних та життєвих ситуаціях, уможливлюючи діяльність освіченої особистості незалежно від локального чи глобального контексту ринку праці. В умовах постійних змін такий фахівець, маючи свободу вибору та оволодівши технологіями прийняття рішень, буде здатним до адаптації і мобільності» [3, с. 30].

Потреба у розв'язання задач, що висунуто перед навчальними закладами на сучасному етапі розвитку суспільства, створює актуальну проблему розвитку у вчителя-філолога професійної компетентності, від рівня якої залежить якість освіти школярів. Професійна підготовка вчителя розглядається як процес виховання особистості, яка усвідомлює своє місце в соціумі, здатна до саморозвитку, самовдосконалення і творчої діяльності. Це передбачає новий підхід до формування професійної компетентності, яка є основою професіоналізму вчителя-словесника [2].

Професіоналізм учителя української мови та літератури є інтегрованим показником його особистісно-діяльнісної сутності, що зумовлена рівнем реалізації громадянської відповідальності, досвіду та професійного обов'язку.

Вагомий внесок у розроблення теоретико-методологічних положень щодо викладання української мови та формування професійної компетентності вчителів-філологів здійснили українські та зарубіжні науковці Н. Голуб, А. Грищенко, Л. Мацько, О. Семеног, С. Шевчук.

Метою статті $є$ аналіз нормативних документів та інформаційно-довідкових матеріалів щодо викладання української мови в закладах освіти АР Крим та визначення стратегічних позицій удосконалення цього процесу.

На етапі нашого дослідження, завданням якого $\epsilon$ вивчення особливостей функціонування української мови в загальноосвітніх закладах Автономної Республіки Крим, аналізувалась офіційна інформаційно-довідкова документація Міністерства освіти і науки, молоді та спорту АР Крим. Узагальнення офіційних матеріалів такого характеру дозволило виокремити стратегічні позиції фахівців, які впливають на управління процесами навчання українській мові. Так, для відтворення загальної картини, яка відображає специфіку навчання українській мові в загальноосвітніх закладах Автономної Республіки Крим, ураховувалась думка спеціалістів про те, що специфіка Криму зумовлена полікультурним соціальним середовищем, що історично склалося. Це зумовлює необхідність розроблення особливих підходів до організації навчального процесу в закладах освіти, вибору конкретних форм і методів розвитку духовного потенціалу учнів, формування толерантного ставлення до людей інших національностей та релігійних переконань.

У таких умовах важлива державна роль належить українській мові як консолідуючому комунікативному чиннику.

У полікультурному освітньому середовищі регіону українська мова повинна допомагати особистості усвідомити своє коріння і тим самим визначити те місце, яке вона займає в суспільстві, прищеплювати людині повагу до інших культур, формувати різнобічну картину світу й забезпечувати адаптацію в постійно змінюваних умовах життя.

Висока мовна культура й комунікативні здібності вчителя-філолога $\epsilon$ не лише важливою характеристикою освітнього середовища, але й фундаментом формування культурного простору загальноосвітнього закладу. 
«Українська мова», на відміну від інших навчальних дисциплін, не тільки предмет вивчення і засіб навчання, вона $є$ головною умовою діалогу, виховання загальної культури й особистісного розвитку учнів - представників різних етносів, релігійних переконань. Історія Криму визначила безальтернативність української мови в забезпеченні мирного співіснування, співпраці і прогресивного розвитку всіх етносів і культур регіону.

Володіння українською мовою сприяе консолідації громадян у розбудові та зміцненні держави, забезпечує доступ до джерел української духовності, дає змогу випускникам загальноосвітніх закладів у повному обсязі реалізувати в різних галузях чи сферах життєдіяльності можливості, життєві потреби, плани, пов'язані з подальшим здобуттям освіти, опануванням спеціальністю [1].

Навчання українській мові в закладах освіти Автономної Республіки Крим здійснюється згідно із Законами України «Про засади державної мовної політики», «Про освіту», «Про загальну середню освіту», Державним стандартом базової і повної середньої освіти.

Реалізацію обов'язкового мінімуму змісту середньої освіти здійснюють навчальні програми для загальноосвітніх навчальних закладів із російською та українською мовами навчання, які рекомендовані Міністерством освіти і науки, молоді та спорту України. Тижневе навантаження учнів 5-11 класів загальноосвітніх закладів під час вивчення галузі «Мови та літератури» складає 57 годин, що відповідає 23,4 \% від загальної кількості дисциплін і $є$ найбільшим відсотковим показником щодо інших предметів. Міністерством освіти та науки, молоді та спорту Автономної Республіки Крим розроблено, погоджено 3 Міністерством освіти та науки, молоді та спорту України та затверджено наказом від 17. 07. 2007 року № 423 Комплексну програму поліпшення вивчення державної мови та мов національних меншин у загальноосвітніх закладах Автономної Республіки Крим.

В усіх загальноосвітніх закладах регіону використовується новаторський досвід, нові педагогічні технології та інновації під час викладання української мови, що прогнозовано забезпечує досягнення позитивних результатів: учні більш вільно орієнтуються у ситуаціях спілкування, складають діалоги згідно із запропонованою ситуацією, підвищується рівень грамотності під час роботи над усним чи письмовим твором. Учні на уроках активні; показниками такої активності є питання, звертання до вчителя, прагнення учнів за власним бажанням брати участь в обговоренні тематичних питань, доповнення відповідей однокласників, бажання висловити свою позицію, прагнення поділитися певною інформацією.

Критерієм оцінювання професійної готовності вчителя-мовника $є$ не лише система сформованих предметних або міжпредметних компетенцій, а й позапредметних, що меншою мірою корелюють 3 навчальними предметами «Українська мова» та «Українська література», вияв у філолога ключових компетенцій, що відображаються в інтелектуальній, комунікативній, інформаційній, суспільно-політичній та особистісній сферах. На сучасному етапі розширюються функції вчителя української мови та літератури, пов'язані 3 пошуковою, науково-дослідницькою, соціальною, культурнопросвітницькою діяльністю.

У системі шкільної підготовки значну увагу приділено мовному й літературному вихованню. Лінгвістичне навчання формує україномовну поведінку, актуалізує лексичну, семантичну, граматичну компетенції, удосконалює уміння й навички особистісномовленнєвої діяльності, виховує особистість, здатну вільно і комунікативно доцільно спілкуватися в різних сферах суспільного життя, та реалізується у факультативах, інтегрованих спецкурсах, пошуковій роботі з мовного родинознавства, лінгвістичного краєзнавства тощо. Через опанування емоційно-оцінного, морально-етичного потенціалу фольклору і літератури у світовому і національному мистецькому контексті відбувається «занурення» до світу української ментальності [4].

Контроль за процесом підвищення професійної кваліфікації вчителів-філологів здійснює Кримський республіканський інститут післядипломної педагогічної освіти. 
Також значний вклад у розвиток освіти в полікультурному середовищі Автономної Республіки Крим вносять вищі навчальні заклади регіону, зокрема Таврійський національний університет ім. В. І. Вернадського, РВНЗ «Кримський гуманітарний університет» (м. Ялта), Кримський інженерно-педагогічний університет, які розробляють наукові мовні проблеми, присвячені полікультурному середовищу Криму, та проводять науково-практичні конференції й форуми з цих питань.

Особливе значення в підвищенні якості навчання українській мові в освітніх закладах може мати здійснення систематичного контролю за виконанням практичної та теоретичної частин державних навчальних програм 3 української мови, проведення постійного внутрішньошкільного моніторингу якості навчання школярів.

Важливу навчальну роль відіграють різноманітні форми додаткової освіти дітей. Прикладом можуть бути щорічні проведення республіканського конкурсу учнівської творчості на мовах народів Криму «Мова - душа народу» та фестивалю «Рідна мова безцінна, та невичерпні духовні багатства народу» в межах Міжнародного дня рідної мови; Всеукраїнського конкурсу - захисту науково-дослідницьких робіт учнів - членів МАН філологічного відділення Кримської малої академії наук «Пошуковець»; республіканського конкурсу юних журналістів, поетів і прозаїків «Мій голос».

Водночас у стані навчання українській мові в загальноосвітніх закладах АР Крим в умовах полікультурного середовища виявляються певні недоліки та нерозв'язані питання.

Необхідністю розв'язання задачі формування особистості в освітньому просторі Криму 3 урахуванням поліетнічності, багатомовності та різноманіття культур у якості пріоритетної.

Аналіз щорічних контрольних зрізів з української мови свідчить про те, що в Автономній Республіці Крим зберігається тенденція до зниження рівня грамотності учнів - орфографічної та пунктуаційної. У школах регіону в роботі вчителів української мови та літератури нерідко порушуються вимоги до унормованого усного та писемного мовлення учнів; оцінювання знань, умінь та навичок з мовного та мовленнєвого розвитку школярів.

Цілісний аналіз якості навчання українській мові дозволив дійти висновків щодо необхідності наукового розроблення комплексу заходів з організаційного, ресурсного та науково-методичного забезпечення навчання українській мові як державній. Необхідна модернізація педагогічних підходів і технологій викладання української мови 3 урахуванням якості полікультурного середовища.

Отже, проаналізувавши інформаційно-довідкову документацію та узагальнивши офіційні матеріали, можемо дійти висновку, що на території Автономної Республіки Крим необхідно постійно працювати над процесом підвищення професійної компетентності вчителів української мови та літератури, систематично проводити контроль стану викладання української мови у регіоні, забезпечувати роботу 3 використання інформаційно-комунікаційних технологій у навчальному процесі, поповнювати навчально-матеріальну базу та навчально-методичне забезпечення кабінетів української мови та літератури, продовжувати вивчення та впровадження ППО у практику роботи вчителів-філологів.

\section{Література}

1. Державні стандарти базової і повної середньої освіти в Україні. Освітня галузь «Мови і літератури» // Інформаційний збірник МО України. - 2004. - № 1-2. - 164 с. 2. Картава Ю. К. Лінгвістична компетентність як важлива складова професіоналізму вчителя-філолога / Ю. К. Картава. // Матеріали восьмої Міжнародної інтернет-конференції «Україна наукова». - К. : ТОВ «ТК Меганом», 2011. - С. 28-30. 3. Пуховська Л. П. Стратегія розвитку професіоналізму педагогів на зламі століть / Л. П. Пуховська // Післядипломна освіта в Україні. - 2002. - №2.С.29-32. 4. Семеног О. М. Система професійної підготовки майбутніх учителів української мови i літератури (в умовах педагогічного університету): дис. ... д-ра пед.. наук: 13.00.04./ О. М. Семеног. К., 2005. $-476 \mathrm{c}$. 